Original Research

\title{
Collaborative Model of Teachers, Students and Families to Improve Parents Knowledge and Skills on Food Safety of Elementary School Students
}

\author{
Sigit Mulyono, Elly Nurachmah, Junaiti Sahar and Sabarinah Prasetyo
}

Faculty of Nursing, Universitas Indonesia, Depok, Indonesia

\begin{abstract}
Introduction: School-age children in Indonesia are at risk of health problems due to food insecurity. Parents have a very important role in preparing safe food, both at home and for lunch at school. The aim of this study was to determine the effect of a collaboration model of teachers, students, and their families (KOGUSIGA) towards the parents' knowledge and skills on the food safety of elementary school students.

Methods: This study applied a quasi-experiment design pre- and post-test with a control group. The subject sample used was the total sampling method, involving 206 parents. The study was conducted for over 10 weeks, supported with modules for nurses and parents, textbooks for the students and their families, and a student workbook.

Results: The results showed that the KOGUSIGA model is associated significantly with greater knowledge ( $p$-value $=0.000$; with a mean difference of 20.23) and the parent's skills ( $p$-value $=0.000$; with a mean difference of 12.3 ) to do with food insecurity.

Conclusion: The KOGUSIGA model tends to improve the knowledge and skills parents significantly, in relation to the food safety of the students. It is expected that the KOGUSIGA model will be applied under the community health nursing/school health nurses' supervision.
\end{abstract}

\section{ARTICLE HISTORY}

Received: Oct 05, 2017

Accepted: June 06, 2018

\section{KEYWORDS}

school age children; parents; food safety; collaboration; school health nursing

\section{CONTACT}

Sigit Mulyono

$\triangle$ sigit@ui.ac.id

$\supseteqq$ Faculty of Nursing, Universitas Indonesia, Depok, Indonesia

Cite this as: Mulyono, S., Nurachmah, E., Sahar, J., \& Prasetyo, S. (2018). Collaborative Model of Teachers, Students, and Families to Improve Parents Knowledge and Skills on Food Safety of Elementary School Students. Jurnal Ners, 13(1), 1-8. doi:http://dx.doi.org/10.20473/jn.v13i1.6061

\section{INTRODUCTION}

School-age is a phase when children are between 6 to 12 years of age (Brown, et. al., 2005). During this phase, motor development is relatively fast yet not their intellectual development yet. While chool-age children start to develop logical thinking, they are still attached to perceptual facts (Brown, et. al., 2005; Wong, Eaton, Wilson, Winkelstein, \& Schartz, 2008). Consequently, School Age Children are not yet able to predict level of danger, including the hazard of unsafe food (Brown, et. al., 2005; Siburian, 2012). This fact is the main cause behind why most school-age children experience various kinds of health threat related to food safety, such as food-borne diseases, food ingredients containing dangerous substances, and not meeting their nutritional needs (FAO/WHO, 2002). Safe food is defined as food which is balanced in terms of the fulfilment of one's daily energy, protein, mineral, vitamins, and other nutrition component needs, and not causing illness (Gross, Cohen, \& Kahan, 2006). The term "not causing illness" means that the food is safe from microorganism pollution that causes disease and is free from hazardous chemicals. Many cases of sickness happen because the level of food safety is low. The results of the Asia Food Safety Conference held in Malaysia in 2014 showed that cases of food-borne illnesses are still the main priority. Food that was contaminated, especially by microorganisms, was the main cause (FAO/WHO, 2004). Food contaminated by E. coli bacteria was responsible for more 3,950 cases of illness and 53 deaths in European countries in 2017 (EFSA, 2012).

The effect of low food security is very dangerous for school age children, as it can lead to death. Food poisoning cases in India caused the death of 23 elementary school students (NIDM, 2013). In Indonesia, cases of health problems related to food safety in children is relatively high. Based on a research study by Andarwulan et al. (2009), in 
Indonesia, health problems caused by food were experienced by $21.4 \%$ of children in Bogor, Indonesia, where $75.5 \%$ of them were school age children. Food poisoning cases was at the top of the list.

Food-borne sickness is one example of poor safety food. These phenomena were the main issue of the discussed health topic and became one of the world spotlights declared by FAO/WHO at the Forum of Safety Regulation in Morocco, 2002. The forum asserted that the diseases caused by food contribute to a number of illnesses and deaths in the population of school age children. Aside from food-borne diseases because of food, the health problem cases caused by a lack of nutrition were also high.

Based on a research study conducted in 2011, out of 517 elementary schools or Islamic elementary schools (MI) in the city of Depok, there were 1,048 children with thin bodies and 7 children suffering from malnutrition (with a severely thin body) (Dinas Kesehatan Kota Depok, 2012). A survey conducted in one of the elementary schools in Depok found that $36.76 \%$ of the school population was made up of malnutrition cases (Kusumaningsih, 2010).

In addition to food-borne diseases and the exposure to dangerous chemicals, the next food safety issue was nutrition intake, which does not meet the daily requirements, causing malnutrition. The lack of nutritional intake is a common problem in the school age children (Stanhope \& Lancaster, 2004; Allender \& Spradley, 2005). Based on Basic Health Research (Riskesdas) in 2010 regarding nutrition, it showed that the level of nutrition fulfilment is still worrying (Kementerian Kesehatan Republik Indonesia, 2011). On a national scale, $40.7 \%$ of Indonesian people consume less food than the minimum daily standard or do not meet the national standard nutritional adequacy rate. The problem of a lack of protein consumption happened in all age groups, especially school age children (Kementerian Kesehatan Republik Indonesia, 2011).

The condition above has forced the efforts of nutrition fulfilment and food safety to be increased as much as possible. One of the efforts made by the WHO is the Global Strategy for Food Safety, and its main strategy is to provide and promote health campaigns. Unfortunately, in Indonesia, health campaign programs are not integrative, making them not fully effective. There needs to be an integrated health program, which is like the UKS (School Health Unit) program.

An effort towards a more comprehensive and integrative approach has been introduced by the Ministry of Health through the Advocacy, Cultivating Atmosphere, and Community Empowerment model (Advokasi, Bina suasana, dan Gerakan model pemberdayaan masyarakat or $\mathrm{ABG}$ ). The ABG strategy is the main strategy set forth in all health promotion guides in various settings throughout Indonesia, including in the institutional setting of education. One of the programs that it runs is UKS. However, ABG has not succeeded yet in improving the students' health condition. This can happen because the strategy of
ABG is still in the concept stage. There is no clear operational guidance, and there is even an absence of trained human resources to run it (Mulyono, 2003). In addition, there is still no optimal coordination of teachers, families, and students in the implementation of the UKS program (Widjajanti, 2012). MacLellan, Taylor \& Freeze (2009) and Ratnapradipa (2011) have suggested that parents and teachers are important role models for students in the formation of safe and balanced eating behaviour. This has caused the ABG strategy through the UKS program to still be difficult to apply in the field, especially when dealing with the problem of food safety in schools. Therefore, an easy to implement program is needed by empowering the human resources that can collaborate with teachers, students and their families. This will play a role in the process of establishing healthy behaviour in schoolaged children, one of which is helped by a school health nurse (school health nursing).

The researchers then developed a model of nursing care in schools that aims to improve the role of nurses in collaborating with teachers, students, and their families, which will trigger changes in food safety practice. The model being developed is called the Teachers, Students, and Families Collaboration (Kolaborasi Guru, Siswa, dan Keluarga or KOGUSIGA). KOGUSIGA emphasises on a food safety program to develop the habit of choosing, handling, and consuming healthy and safe food through the collaboration of teachers, students, and their families.

The Indonesian National Agency of Food and Drug Control (2005) explained that the use of hazardous additive substances or the contamination of other chemicals in food could happen because of a lack of understanding and poor family behaviour to do with food safety. The family is the micro system that interacts the most with a child and influences his/her behaviour. Family plays an important role in determining healthy behaviour in everyday life, including children's behaviour in terms of the fulfilment of nutritional needs. FAO (2004) reported that the percentage of food sources that have caused food poisoning was $47.1 \%$ from household foods and $14.4 \%$ from snack foods. In addition, the Secretariat General of the Food Intelligence Network (2005) stated that the setting where food poisoning took place the most was in the home environment, which was $39.9 \%$, and the school environment, which was $23.5 \%$. A study by the Minister of Health also showed that the school and home environment could be the providers of less-healthy food (Sekretariat Jenderal Jejaring Intelijen Pangan, 2005). Therefore, the home environment (family) needs to be provided with education regarding food safety. The KOSUSIGA model can be the alternative to family nursing interventions in order to improve the role of the family regarding the food safety program.

Parents are the role models for their children, and they can influence the behaviour of having a safe and balance diet in school age children. Parents are also companions, as well as being educators for their 
children while they are going about their daily activities. Consequently, it is important for parents to acknowledge and understand possible health problems and disorders, which are relatively wide and complex, especially about food safety. This research aims to identify the influence of the KOGUSIGA model on the improvement of the knowledge and skills of parents regarding food safety in elementary school students.

\section{MATERIALS AND METHODS}

The design of this research was a quasi-experiment pre-post test. The research was conducted in an elementary school in Depok, from April to June 2014. The taking of samples was carried out by using the total sampling technique, and the total samples were 206 respondents who were parents, who matched the inclusion criteria. There were 103 respondents in the intervention group and 103 respondents in the control group.

Selected respondents supplied personal informed consent prior to the study. The KOGUSIGA intervention model was applied by the nurses, who had received the appropriate training according to particular stages. The nurses educated the parents, both mothers and fathers, in the class by inviting them to come into the school. The media used in this study was the modules, containing training materials about the nutritional needs of school age children, the selection of safe food, cooking safe food, serving safe food, storing safe food, choosing healthy snacks, and the washing of hands. The book was tested by BPOM personnel, as well as the health promotion program, nutrition program, environmental health program, and the School Health program. The media used was workbooks as an evaluation book, especially designed for parents and the students. The researcher was committed to the research ethics of each and every respondent participating. According to the National Commission on the Health Research Ethics of the Indonesian Minister of Health (2006), there are four principal research ethics: beneficence, respect for persons, non-malfeasance, and justice. Ethical clearance was issued by The Research Ethic Committee of the Faculty of Nursing, of Universitas Indonesia.

The process of data retrieval was done by the respondents filling out the questionnaires by way of an interview in the form of the parents' and students' demographic information, the parents' knowledge and the parents' skills. The questions regarding the demographic information (parents and the homeroom teachers) were to do with age, sex, level of education, level of economy based on salary, and the relationship to the students. The questions about the level of family knowledge consisted of 9 questions about nutritional content with pictures and 25 yes/no questions. The scale of family skills was also measured by using questionnaires, consisting of 25 "always - often - seldom - never" questions. The family skills questions were about the skills held on living a clean and healthy life (PHBS), safe food, food handling, food storage, balanced diet, the nutritional content of food, and food serving. The maximum score before being given the intervention on the knowledge variables was 5 , whereas after being given the intervention, the maximum score of knowledge increased to 7 . The maximum score before being given the intervention on the skill variable was 26 , whereas after being given the intervention, the maximum skill score increased to 55 .

To analyse the data, a specialised computer program was employed. To determine the change before and after the inclusion of the KOGUSIGA intervention model, the data was analysed using a bivariate test. The Paired T-test was used on the numeric data for a comparison between the two paired groups with a normal data distribution, and the alternative Wilcoxon test was used for the abnormal data distribution. Both the Paired T-test and Wilcoxon test were compared (Dahlan, 2009).

\section{RESULTS}

The characteristic of the respondents based on the average age of the students' parents in the intervention group was 38.3 years old and this was almost identical to the average of the control group, which was 40.1 years old. The youngest in the intervention group was 18 years old and the oldest was 71 years old $(\mathrm{Sd}=8.22)$, while in the control group, the youngest was 20 years old and the oldest was 62 years old ( $\mathrm{Sd}=7.86$ ) (Table 1$)$.

In addition, the sex of the parents in the intervention group was dominated by females (79.6\%), as well the control group by $73.8 \%$. In terms of the level of education, in the intervention group, $47.6 \%$ of the respondents were high-school graduates while in the control group, more than half of the respondents (53.4\%) were high-school graduates (Table 2).

The data on the parents' income in the both intervention and control group was relatively identical. More than half of the respondents earned less than 2.4 million rupiah per month, with $55.3 \%$ in the intervention group and $57.3 \%$ in control group. In terms of the relationship with the students, both groups were almost similar in that the respondents were taking care of their biological children, with the data showing $89.3 \%$ in the intervention group and $90.3 \%$ in the control group respectively (Table 3).

The questionnaire analysis on the parents' knowledge showed that the parents who were given the KOGUSIGA intervention experienced an improvement in their awareness to do with the importance of having breakfast. Before the intervention, the total percentage of the parents correctly responding to the statement "having breakfast does not affect focus in learning process" was only $39.8 \%$. After the intervention, this increased to $78.6 \%$. Family knowledge about the importance of washing the ingredients before cooking them increased from $68.9 \%$ before the intervention to 
Table 1. Distribution of the Parents/Guardians of the Students by Age in both the Intervention and Control Group ( $\mathrm{n}=206)$

\begin{tabular}{llllllll}
\hline Age variable & n & Mean & Median & Min & Max & Sd & p value \\
\hline Intervention group & 103 & 38.25 & 38.00 & 18 & 71 & 8.22 & \multirow{2}{*}{0.191} \\
Control group & 103 & 40.07 & 39.00 & 20 & 62 & 7.86 & \\
\hline
\end{tabular}

Table 2 Distribution of the Parents/Guardians of the Students by Sex and Level of Education in both the Intervention and Control Group ( $\mathrm{n}=206)$

\begin{tabular}{|c|c|c|c|c|c|}
\hline \multirow[b]{2}{*}{ Variable } & \multicolumn{2}{|c|}{ Intervention group } & \multicolumn{2}{|c|}{ Control group } & \multirow{2}{*}{$p$ value } \\
\hline & $\mathbf{n}$ & $\%$ & $\mathbf{n}$ & $\%$ & \\
\hline \multicolumn{6}{|l|}{ Gender } \\
\hline Male & 21 & 20.4 & 27 & 26.2 & \multirow{3}{*}{0.323} \\
\hline Female & 82 & 79.6 & 76 & 73.8 & \\
\hline Total & 103 & 100.0 & 103 & 100.0 & \\
\hline \multicolumn{6}{|l|}{ Level of education } \\
\hline$<$ Senior High School & 42 & 40.9 & 43 & 41.7 & \multirow{4}{*}{0.230} \\
\hline Senior High School & 49 & 47.6 & 55 & 53.4 & \\
\hline College & 12 & 11.7 & 5 & 4.9 & \\
\hline Total & 103 & 100.0 & 103 & 100.0 & \\
\hline
\end{tabular}

Table 3. Parents/Guardians of the Students by Income and the Relationship with the Children in both the Intervention and Control Group ( $\mathrm{n}=206)$

\begin{tabular}{|c|c|c|c|c|c|}
\hline \multirow{2}{*}{ Variable } & \multicolumn{2}{|c|}{ Intervention group } & \multicolumn{2}{|c|}{ Control group } & \multirow{2}{*}{ p value } \\
\hline & $\mathbf{n}$ & $\%$ & $\mathbf{n}$ & $\%$ & \\
\hline \multicolumn{6}{|l|}{ Income } \\
\hline$<\mathrm{UMR}^{*}$ & 57 & 55.3 & 59 & 57.3 & \multirow{3}{*}{0.780} \\
\hline$\geq \mathrm{UMR}^{*}$ & 46 & 44.7 & 44 & 42.7 & \\
\hline Total & 103 & 100.0 & 103 & 100.0 & \\
\hline \multicolumn{6}{|l|}{ Relationship with student } \\
\hline Biological children & 92 & 89.3 & 93 & 90.3 & \multirow{3}{*}{0.198} \\
\hline Not the biological children & 11 & 10.68 & 10 & 9.7 & \\
\hline Total & 103 & 100.0 & 103 & 100,0 & \\
\hline
\end{tabular}

*UMR: Upah Minimum Regional (Regional Minimum Wages)

Table 4. The effect of the KOGUSIGA Intervention Model towards the Knowledge and Skills of Families in the Intervention and Control Groups ( $\mathrm{n}=206)$

\begin{tabular}{|c|c|c|c|c|c|c|c|c|c|}
\hline Group & $\mathrm{n}$ & $\overline{\boldsymbol{x}}$ Pre (\%) & s & $\begin{array}{l}\text { Normality } \\
\text { Test } * * * * *\end{array}$ & $\begin{array}{ll}\bar{x} & \text { Post } \\
(\%) & \end{array}$ & s & $\begin{array}{l}\text { Normality } \\
\text { test } * * * * *\end{array}$ & $\begin{array}{l}\% \\
\text { margin } \\
\overline{\boldsymbol{x}}\end{array}$ & $\begin{array}{l}\text { p-value } \\
1 \text {-tailed } \\
\text { pre-post }\end{array}$ \\
\hline \multicolumn{10}{|l|}{ Knowledge } \\
\hline Intervention & 103 & $\begin{array}{l}12.9 \\
(38,21)\end{array}$ & 5.39 & 0.000 & $\begin{array}{l}19.87 \\
(58.44)\end{array}$ & 3.81 & 0.013 & 20.23 & $0.000^{*}$ \\
\hline Control & 103 & $\begin{array}{l}20.66 \\
(60.76) \\
\end{array}$ & 3.87 & 0.030 & $\begin{array}{l}20.64 \\
(60.70) \\
\end{array}$ & 3.97 & 0.014 & -0.06 & $0.431^{*}$ \\
\hline \multicolumn{10}{|l|}{ Skills } \\
\hline Intervention & 103 & 64.61 & 16.04 & 0.000 & 76.91 & 8.44 & 0.200 & 12.3 & $0.000 *$ \\
\hline Control & 103 & 71.43 & 9.67 & 0.200 & 79.68 & 8.30 & 0.123 & 8.25 & $0.000^{* *}$ \\
\hline
\end{tabular}

Note: *Wilcoxon Test, ${ }^{* *}$ T-Test Paired, ${ }^{* * * *}$ T-Test Independent, *****Kolmogorov-Smirnov Test,

s: deviation standard

91.3\% after the intervention. However, the awareness of parents in using clean water was relatively high $(87.4 \%)$ throughout.

The results of the questionnaire analysis on parents' skill showed an improvement in the knowledge regarding the importance of having breakfast, followed by an improvement in the skill of preparing a breakfast meal. This was proven by the increase in the percentage of parents responding with "always" for the statement "I prepare breakfast for my children", from $40.8 \%$ before the intervention to 83.5\% after the KOGUSIGA intervention. The parents' skill of choosing clean and safe wrapped food also improved. Before the intervention, there were only $51.5 \%$ of parents responding with "always", and after the intervention, this increased to $86.4 \%$. A positive change in breakfast behaviour should be improved, since the number of school-age children who do not eat breakfast in several big cities is considerably low, at $16.9-59.0 \%$ (Hardiansyah \& Aries, 2012). Education on nutrition health education involving the parents in relation to KOGUSIGA can be implemented in other schools in order to improve the habit of having breakfast among the students. A research study conducted by Fries, Martin, \& Horst (2017) 
showed that the parents' skill of preparing a packed meal was related to their children's health.

\section{DISCUSSION}

The research showed that there was a significant improvement in the average knowledge and skills of parents in the intervention group after being treated with the KOGUSIGA intervention model, whereas in the control group, there was no improvement shown in the knowledge and skills of the parents. The questionnaire analysis of the parents' knowledge showed that parents who were given the KOGUSIGA intervention experienced an improvement of their awareness about the importance of breakfast for the students. Before the intervention, the total percentage of parents correctly responding to the statement "having breakfast does not affect focus in learning process" was only $39.8 \%$, whereas after the intervention, it increased to $78.6 \%$. Family knowledge about the importance of washing the ingredients before cooking them increased from $68.9 \%$ before the intervention to $91.3 \%$ after the intervention. However, the awareness of parents in using clean water was relatively high $(87.4 \%)$ in both groups. The control group had more male in the sample, and thus, more educated respondents.

The results of this research are in accordance with the research conducted by Prelip, Thai, Erausquin, \& Slusser (2011), stating that there was a significant improvement in the parents' knowledge and nutrition skills when it came to improving the school-age children's level of nutrition after being given education on nutrition and health for five hours a week. Prelip, et al. believed that the effort to improve the school-age children's level of nutrition must focus on the school-age children's parents by educating them, so then the parents can be the role model when it comes to having a healthy diet for their school age children.

The results of the KOGUSIGA intervention also show that the student skill variable is not effective. This is supported by Safriana's research (2012), which revealed that there is no clear relationship between nutritional knowledge and the schools in choosing snacks. Things that can be explained by the knowledge obtained by the child is only limited to knowledge, while the effect of consuming unsafe food, unhealthy food, and a lack of nutrients was not sufficient. Dixey et al. (2001) in Ellis (2007) mentioned that children are good at learning what to expect, but children will still try to do what they like. Eliasen (2007) said that the acceptance of new foods for children, and changing their eating habits is easy. Intensive communication between the students and their parents is the way forward for mutual learning, based on a research study conducted by Ratnapradipa, et. al (2011), using the Child-to-Parent Instruction model.

Although overall there was an increase in knowledge, the parents' level of knowledge about the definition of healthy food, which is food that has been cleanly served, was still low, even before and after the intervention. Before the intervention, the parents who correctly responded only made up $4.9 \%$. After the intervention, the level of knowledge about the given point did not show a significant improvement, with the respondents who correctly responded making up 16.5\%. Saadia (2015), in her research study, argued that there was no significant difference in the parents' knowledge before and after the health education program. Ahmad asserted that naturally, every parent has decent level of basic knowledge concerning the nutrition that is appropriate for their children.

Parents have the willingness to be able to provide safe and nutritious food, so they have to also figure out what should be served to their children. However, while there was no difference in the level of knowledge, it was not an indication that all parents showed a similar attitude to nutrition intake, since the knowledge that they possessed did not necessarily confirm that the parents would apply what they knew. To overcome this situation, it is needed to routinely evaluate and review the parents' motivation to feed and serve food. In the KOGUSIGA intervention model, parents and nurses routinely evaluated the students and families' eating behavior using a workbook once a week. When the evaluation score was below average, teachers or nurses provided a consultation. Hence, when implementing the KOGUSIGA model in the future, the evaluation and consultation program must be prioritised.

Based on the concept of the Health Belief Model by Rosenstock (1990) cited by Allender, Rector, Warner (2008), the individual's ability to obtain nutritional fulfilment was determined by the students' knowledge, attitude, and skill in relation to food safety. The KOGUSIGA model adopted the Health Belief Model by preparing the school-age children to improve their skills when it came to choosing safe food. In this model, there were attempts to transfer the knowledge about food safety to improve the awareness of the advantage of when students, teachers and families can fulfil their nutritional needs. The perception on the risks experienced when it comes to unhealthy food and snacks in the school environment forces students, teachers, and parents to adopt a healthier lifestyle.

Knowledge about the importance of monitoring nutritional adequacy that the parents acquired from the training and modules encouraged the improvement of the skill of monitoring nutrition. Before the intervention, the number of parents responding with "always" and "often" was only $39.8 \%$ and $20.4 \%$ respectively, while after the intervention, the percentage increased to $69.9 \%$ and $25.2 \%$. However, the improvement in knowledge about the importance of doing exercise was not followed by the skill improvement. Before the intervention, only $14.6 \%$ of respondents responded with "always" to the statement "I do exercise regularly with my children". After the intervention, there was no significant improvement, as it remained only $16.5 \%$. Developing 
the habit of doing regular exercise is something that takes motivation, time, and is done gradually. Rodearmel et al. (2006), in their research on the prevention of obesity in children 8-13 years old involving their parents, proved that it took 13 weeks and a gradual process to create a positive change in students and parents IMT. We, as researchers, realised that this point was not maximised through the monitoring of students and family activity.

Regularly doing exercise is one of the indicators of a family with PHBS, which means the family is capable of preserving, improving and protecting the health of each and every member of the family from the threat of disease and a less-conducive and unhealthy environment (Kementerian Kesehatan Republik Indonesia, 2011). In addition, The Message of Balanced Nutrition (PGS) of 2014 suggested that physical activity is a part of the fulfilment of a balanced nutritional state. Physical activity involving all kinds of body movement, including doing exercise, is one of the ways to balance the nutritional input and output within our bodies. Aside from regular monitoring, through the KOGUSIGA model, school nurses can cooperate with the community health nurse to improve the activity of students and families through the medium of regular exercise.

The goal of health education on food safety in school-age children is to improve not only the knowledge, but also the skill, of school-age children regarding food safety (Al-sahbib, Husain, \& Khan, 2017). The KOGUSIGA intervention model also affected the parent's awareness regarding the students' consumption behaviour of snack food by asking them what snack food they consumed on a daily basis. Before the intervention, the percentage of parents asking their children was only 33\%, but after the intervention, this improved to $72.8 \%$. However, the parents were not motivated enough to ask the teachers to monitor the students' behaviour on buying snack food while in school. Before the intervention, the number of parents responding with "always" and "often" was $24.3 \%$ and $16.5 \%$. After the intervention, there was only small incremental increase to $26.2 \%$ and $19.4 \%$. Consuming healthy food snacks is an indicator of PHBS in the school environment (Kementerian Kesehatan Republik Indonesia, 2011). The scope and purpose of UKS is the implementation of the good practice of PHBS in schools, since it is composed of the behaviour practiced by students, teachers, and society surrounding the school on the basis of awareness as a result of the learning process. Hence, the improvement of the parents' awareness of the schoolage children's behaviour in consuming safe food snacks in school needs to be boosted. The knowledge possessed by parents encourages them to try to apply the material that has been taught in order to fulfil their children's nutritional needs. However, sometimes parents force their children to consume food that they do not like. This triggers the difficulty in children when it comes to liking that kind of food (Gregory, Paxton, \&Brozovic, 2010).
According to the ecology system theory, there are several factors in the children's environment that can affect safe nutritional fulfilment, which are microsystem, mesosystem, exosystem, and the macrosystem. The microsysystem is a part of an individual directly interacting with his/her social life, such as friends of the same age, family, neighbours, and the school. Through the microsystem, school age children will learn a lot about health behaviour, and the children are not perceived as the passive receiver in this order. The fulfilment of school age children's nutritional needs will also be affected by the mesosystem, which is the school environment including food-selling environments such as the school canteen or cafeteria. Accordingly, in this research, it is necessary to conduct supervise the food-selling activities in schools so that they can fulfil the standards of safe and balance nutrition. The government, by the means of the closest health service units, which are Puskesmas, is part of the exosystem that influences students when it comes to improving their health. In terms of the macrosystem, the part that affects students when it comes to increasing their health condition is culture or customs, religion or beliefs, wisdom and government regulations, and school policies and regulations.

Comprehensive School Health is an integrated and continuous planning program between school affiliates, school activities and the school health service in order to improve the students' physical health, social well-being, and education. This program involves the school community and family support that focuses on shaping the student's behaviour. This development model will form a group process, and it is expected that the processed group will help in the making of a change in the school children's behaviour when it comes to selecting safe and healthy food.

The nurses comprehensively applied KOGUSIGA using intervention strategies in order to improve the food safety of the students. The improvement of the food safety of the students can be seen from their knowledge of food safety, attitude towards food safety, skill of food safety, nutritional fulfilment and the students' nutritional status. The expected health improvement happens gradually and takes time at every stage. It is based on Transtheoretical Theory, stating that there are five stages of health behaviour change: pre-contemplation, contemplation, preparation, action, and maintenance. All five stages are the basis of the stages of behaviour change in the concept of the KOGUSIGA model.

Eating behaviour and nutritional intake is affected by several factors, including parenting, portions, drink consumption, choice of food (such as vegetarian), eating behaviour and eating frequency (The Academy of Nutrition and Dietetics, 2014). Parenting is very influential on a child's eating behaviour. Sometimes parents let their children not to consume the vegetables served, but although they know that vegetables are extremely important, the parents do not to force their children and prefer to give foods that they like, such as snacks. The 
consumption of fruits and vegetables is capable of decreasing the risk of disease and death (Arbury, Jacklitsch, Farquah, Hodgson, \& Lamson, 2014). Both attitudes, being too stern and too tolerant, become obstacles for parents making their children become accustomed to consuming fruits and/or vegetables, minimising unhealthy snacks and spending more time eating with their children. Consequently in applying KOGUSIGA model, the processed group is conducted through some activity to fulfill safe and balance nutrition that are fun and enjoyable to students, teachers and parents. The KOGUSIGA intervention process is a form of cultivating an atmosphere to create a social environment that encourages the students to behave as expected: displaying better food safety consumption behaviour.

\section{CONCLUSION}

The results of the study show that the KOGUSIGA model was proven to significantly improve the parents' knowledge and skills in the intervention group. The KOGUSIGA model is a method of collaborative health education involving cooperation from all parts of the school. The KOGUSIGA model can be a variation of a nursing intervention, which can be integrated by way of the method of health education as a preventive and promotive effort of the School Health Unit (UKS). One main weakness was that the respondents were not randomly selected.

Based on the results of this research, community nurses and school nurses are needed. The implication of this research is to initiate the provision of school nurses to run the nursing care program, using a community nursing intervention to improve food safety in particular and school age children health in general. It was advised, directed to the Minister of Health, the Minister of Education and Primary and Secondary Schools, the Minister of Religious Affairs, and the Ministry of Internal Affairs as the regulators, that the program of UKS can increase the role of the school nurse by empowering nurses from Puskesmas as the implementers of the school health program.

\section{REFERENCES}

Allender, J.A. \& Spradley, B.W. (2005). Community Health Nursing Promoting and Protecting the Public's Health $6^{\text {th }}$ ed. Philadelphia: Lippincott William \& Wilkins.

Allender, J.A., Rector, C., \& Warner, K.D. (2008). Community Health Nursing Promoting and Protecting the Public's Health $6^{\text {th }}$ ed. Philadelphia: Lippincott Williams \& Wilkins.

Al-shabib, N.A., Husain, F.M., \& Khan, J.M. (2017). Study on food safety concerns, knowledge and practices among university students in Saudi Arabia. Food Control, 73, 202-8.

Andarwulan et al. (2009). Laporan penelitian: Monitoring dan verifikasi profil keamanan pangan jajanan anak sekolah (PJAS) nasional tahun 2008. Bogor: Southeast Asian Food and Agricultural Science and Technology (SEAFAST) Center IPB dan Direktorat Surveilan dan Penyuluhan Keamanan Pangan BPOM RI.

Arbury, S., Jacklitsch, B., Farquah, O., Hodgson, M., Lamson, G. (2014). Heat Illness and Death Among Workers - United States , 2012 - 2013. Morbidity and Mortality Weekly Report, 63(31), 2003-10.

Badan Pengawasan Obat dan Makanan Republik Indonesia. (2005a). Peraturan Kepala Badan Pengawasan Obat dan Makanan Republik Indonesia Nomor: HK.00.05.41.1384 tentang Kriteria dan Tata Laksana Pendaftaran Obat Tradisional, Obat Herbal Terstandar dan Fitofarmaka. Retrieved January 5, 2015, from http//bpom.pom.go.id/.

Brown, J.E. et.al. (2005). Nutrition Through the Life Cycle. $2^{\text {nd }}$ ed. Wadsworth: USA.

Dahlan, S. (2009). Statistik untuk Kedokteran dan Kesehatan. Jakarta: Penerbit Salemba.

Dinas Kesehatan Kota Depok. (2012). Visi misi Dinas Kesehatan Kota Depok tahun 2011-2016. Retrieved January 6, 2015, from: http://dinkes.depok.go.id/index.php.

EFSA. (2012). E.coli: Rapid response in a crisis. Retrieved January 6, 2015, from http://www.efsa.europa.eu/en/press/news/120 711.htm.

Eliassen, Erin K,M.S., R.D., \& Wilson, Mary W,PhD., R.D. (2007). Selecting appropriate elementary school nutrition education resources. American Journal of Health Studies, 22(4), 224-227. Retrieved from

Ellis. N. R (2007). The effect of nutrition knowledge on food choices and body mass index percentile rankings of elementary school children: results from an in-school nutrition education program. Tesis. University of Central Florida, Ann Arbor (UMI:3276356).

FAO/WHO. (2002). Pan-European Conference on Food Safety and Quality. Final report. Rome: FAO \& WHO.

FAO/WHO. (2004). Food Safety for Asia and the Pacific. Report year. Rome: FAO/WHO.

Fries, L.R., Martin, N., \& Horst, K.V. (2017). Physiology $\&$ behavior parent-child mealtime interactions associated with toddlers refusals of novel and familiar foods. Physiol Behav, 176, 93-100.

Gregory, J.E., Paxton, S.J., \& Brozovic, A.M. (2010). Pressure to eat and restriction are associated with child eating behaviours and maternal concern about child weight, but not child body mass index, in 2- to 4-year-old children. Appetite, 54(3), 5506.

Gross, S., Cohen, H.A., \& Kahan, E. (2006). Survey of parents, nurses, and school principals on their perceptions of the controversial role of schools in health promotion. Pediatrics International: Official Journal of The Japan Pediatric Society, 48(1), 44 7.

Hardinsyah \& Aries, M. (2012). Jenis pangan sarapan dan sarapannya dalam asupan gizi harian anak usia 6 - 12 tahun di Indonesia. Jurnal Gizi dan Pangan, 7(2), 89-96. 
Kementerian Kesehatan Republik Indonesia. (2011). Pedoman perilaku hidup bersih dan sehat (PHBS). Retrieved January 6, 2015, from http://depkes.go.id/.

Kementerian Kesehatan RI. (2014). Panduan Gizi Seimbang 2014. Jakarta: Kementerian Kesehatan RI.

Komisi Nasional Etik Penelitian Kesehatan Departemen Kesehatan RI. (2006). Pedoman nasional etik penelitian kesehatan. Retrieved January 6, 2015, from http://perpustakaan.depkes.go.id.

Kusumaningsih, I. (2010). Pemberdayaan siswa sebagai motivator untuk mencegah gizi kurang pada kelompok anak sekolah dasar ratujaya III di Kelurahan Ratujaya, Kota Depok. Specialist's Final Report. Faculty of Nursing Universitas Indonesia.

MacLellan, Taylor, \& Freeze. (2009). Developing school nutrition policies: enabling and barrier factors. Can J Diet Pract Res Winter, 70(4), pp 16671

Mulyono, S. (2003). Evaluation of Nutritional Behavior Change: An Intervention Study of Rural Extension Clientele. Thesis: Canada.

NIDM. (2013). Disaster Update. Retrieved January 6, 2015, from http://nidm.gov.in/PDF/DU/2013/October/2410-13.pdf.

Prelip, M., Thai, C.L., Erausquin, J.T., \& Slusser, W. (2011). Improving low-income parents' fruit and vegetable intake and their potential to impact children's nutrition. Health Education, 111(5), 391-411.

Ratnapradipa, Quiliam, Wier, \& Rhodes. (2011). Food safety education: Child-to-parent instruction in an immigrant population. Journal of Environmental Health, 73(6), 70-5.

Rodearmel, S.J., et. al. (2006). A family-based approach to preventing excessive weight gain. Obesity, 14(8), 393-401.
Saadia, A. (2015). Comparison of knowledge, attitude, and behavior in parents of head start preschoolers before and after nutrition education, (Dissertation on the internet). Illinois: Nothern Illinois University. Retrieved January 20, 2015, from ProQuest Dissertations Publishing.

Safriana. (2012). Perilaku memilih jajanan pada siswa sekolah dasar di SDN Garot Kecamatan Darul Imarah, Kabupaten Aceh Besar Tahun 2012. Skripsi: FKM UI.

Sekretariat Jenderal Jejaring Intelijen Pangan. (2005). Kejadian Luar Biasa Keracunan Pangan. Food Watch Sistem Keamanan Pangan Terpadu.

Siburian. (2012). Pengetahuan Anak Sekolah Dasar terhadap Pencegahan Penyakit Diare di SD 098167 RSS Perumnas Kerasaan Kec. Pematang Badar Kab. Simalungun, (bachelor's thesis). Universitas Sumatera Utara.

Stanhope, M. \& Lancaster, J. (2004). Public Health Nursing: Population-Centered Health Care in The Community, $6^{\text {th }}$ ed. Philadelphia: Elsevier Health Sciences.

The Academy of Nutrition and Dietetics. (2014). Position of the academy of nutrition and dietetics: Nutrition guidance for healthy children ages 2 to 11 Years. Journal of The Academy of Nutrition and Dietetics, 114(8), 1257-76.

Widjajati, W. (2012). Pengembangan Usaha Kesehatan Sekolah (UKS). Presentasi pada Rapat Kerja Nasional (UKS) 2012, Jakarta. Diunduh dari http://dikdas.kemdikbud.go.id/application/medi a/file/Rakernas\%20UKS\%202012/Pengembang an\%20Usaha\%20Kesehatan\%20Sekolah\%20\%2 8UKS\%29.ppt.

Wong, D.L., Eaton, M.H., Wilson, D., Winkelstein, M.L., \& Schartz, P. (2008). Buku Ajar Keperawatan Pediatrik Wong. Edisi 6. Translator: Sutarna A. Jakarta: EGC. 